\title{
Legume-based mixed intercropping systems may lower agricultural born $\mathrm{N}_{2} \mathrm{O}$ emissions
}

\author{
Mehmet Senbayram ${ }^{1,2^{*}}$, Christian Wenthe ${ }^{1}$, Annika Lingner ${ }^{1}$, Johannes Isselstein ${ }^{3}$, Horst Steinmann ${ }^{4}$, \\ Cengiz Kaya ${ }^{2}$ and Sarah Köbke ${ }^{5}$
}

\begin{abstract}
Background: The area used for bioenergy crops (annual row crops (e.g., wheat, maize), herbaceous perennial grasses, and short-rotation woody crops (e.g., poplar)) is increasing because the substitution of fossil fuels by bioenergy is promoted as an option to reduce greenhouse gas (GHG) emissions. However, biomass used for bioenergy production is not per se environmentally benign, since bioenergy crop production is associated with negative side effects such as $\mathrm{GHG}$ emissions from soil (dominated by $\mathrm{N}_{2} \mathrm{O}$ ). $\mathrm{N}_{2} \mathrm{O}$ emissions vary greatly in space and time; thus, direct comparison of soil $\mathrm{N}_{2} \mathrm{O}$ fluxes from various agro-ecosystems is certainly crucial for the assessment of the GHG reduction potential from energy crops.

Methods: Therefore, our study aimed to evaluate the two different agro-ecosystems (cropland and agro-forestry) cultivated in central Germany for their environmental impact. In a 1-year field experiment, we compared $\mathrm{N}_{2} \mathrm{O}$ fluxes from cropland (non-fertilized wheat, $\mathrm{N}$-fertilized wheat, non-fertilized faba bean, and wheat mixed intercropping with faba bean) and agro-forestry (non-fertilized poplar, N-fertilized poplar, non-fertilized Robinia, and poplar mixed intercropping with Robinia) as a randomized split-block design.
\end{abstract}

Results: Rainfall at the field site was slightly over average during the period from 1 April to 1 July in 2014 (201 mm rain) and considerably below average during the same period in 2015 (100 mm rain). Cumulative mean $\mathrm{N}_{2} \mathrm{O}$ fluxes were up to five fold higher in agro-forestry than in arable crop treatments during 2014 growing period. We hypothesized that the difference in $\mathrm{N}_{2} \mathrm{O}$ emissions when comparing arable land and agro-forestry was mainly due to the limited water and nutrient uptake of plantations during the first year. Among the arable crops (wheat, $\mathrm{N}$-fertilized wheat, wheat mixed intercropped with bean, and bean), seasonal and annual $\mathrm{N}_{2} \mathrm{O}$ emissions were highest in soils when faba bean was grown as a mono-crop. On the other hand, cumulative mean $\mathrm{N}_{2} \mathrm{O}$ fluxes were $31 \%$ lower $(p<0.05)$ when faba bean mixed with wheat than in soils planted with $\mathrm{N}$-fertilized wheat.

Conclusions: The latter clearly suggests that using legume crops as intercrop or mixed crop in wheat may significantly mitigate fertilizer-derived $\mathrm{N}_{2} \mathrm{O}$ fluxes and may be an effective proxy for increasing GHG emission savings for energy crops.

\footnotetext{
* Correspondence: mehmetsenbayram6@yahoo.co.uk

'Institute of Applied Plant Nutrition, University of Gottingen,

Carl-Sprengel-Weg 1, Gottingen 37075, Germany

${ }^{2}$ Present Address: Department of Plant Nutrition and Soil Science, University

of Harran, SanliUrfa TR-63000, Turkey

Full list of author information is available at the end of the article
}

\section{说) Springer}

(c) 2015 Senbayram et al. Open Access This article is distributed under the terms of the Creative Commons Attribution 4.0 International License (http://creativecommons.org/licenses/by/4.0/), which permits unrestricted use, distribution, and reproduction in any medium, provided you give appropriate credit to the original author(s) and the source, provide a link to the Creative Commons license, and indicate if changes were made. 


\section{Background}

The observed increase in global average temperatures over the last decades is very likely due to the observed increase in anthropogenic greenhouse gas concentrations in the atmosphere. Nitrous oxide $\left(\mathrm{N}_{2} \mathrm{O}\right)$ is a potent greenhouse gas as it absorbs long-wave radiation and contributes to the reduction of the ozone layer in the stratosphere [1]. Data from the ice-core analysis show that for thousands of years, mean atmospheric $\mathrm{N}_{2} \mathrm{O}$ concentrations were close to 270 ppbv; however, the latter increased about $20 \%$ in recent years [2, 3]. The Intergovernmental Panel on Climate Change (IPCC) Third Assessment Report identified microbial production of $\mathrm{N}_{2} \mathrm{O}$ in expanding and fertilized agricultural lands as a primary driver of this increase [4]. However, large uncertainties remain on the estimates of $\mathrm{N}_{2} \mathrm{O}$ fluxes from the biosphere [2,5] due to complex interactions between the related processes and controls on production, consumption, and transport through the soil and on the release into the atmosphere $[6,7]$.

High-yielding agricultural systems have specifically high nitrogen $(\mathrm{N})$ demand which cannot be supplied by soil $\mathrm{N}$ reserves. Therefore, additional $\mathrm{N}$ input is needed; however, in most agricultural land-use systems, the application of organic and inorganic nitrogen fertilizers triggers the emissions of anthropogenic $\mathrm{N}_{2} \mathrm{O}$ emissions. The present IPCC default factor for direct $\mathrm{N}_{2} \mathrm{O}$ emissions arising from the nitrogenous fertilizer application to managed soils is $1 \%$. However, soil $\mathrm{N}_{2} \mathrm{O}$ emissions vary significantly depending on soil type, plant species, climate, crop rotation, tillage method, and fertilizer application rates [4]. At high $\mathrm{N}_{2} \mathrm{O}$-emitting sites, most $\mathrm{N}_{2} \mathrm{O}$ release is characterized by short peak emissions (up to $90 \%$ of the annual emissions) connected mainly to (i) precipitation events and change in soil moisture [8-10], (ii) $\mathrm{N}$ fertilization [11-13], (ii) freeze-thaw cycle [14], and (iv) soil tillage [15]. Such peak $\mathrm{N}_{2} \mathrm{O}$ emissions from soils are highly variable in space and time; thus, measuring and quantifying variance in $\mathrm{N}_{2} \mathrm{O}$ emissions are rather difficult, and there are only a few field experiments available allowing long-term comparison of various crops and other factors [16]. It is absolutely crucial to simulate such $\mathrm{N}_{2} \mathrm{O}$ peak events and to identify the driving factors in order to be able to develop mitigation options.

The main microbial reactions involved in the production of $\mathrm{N}_{2} \mathrm{O}$ are nitrification (oxidation of $\mathrm{NH}_{4}^{+}$to $\mathrm{NO}_{3}{ }^{-}$) and denitrification (reduction of $\mathrm{NO}_{3}{ }^{-}$, via $\mathrm{NO}, \mathrm{N}_{2} \mathrm{O}$, to $\mathrm{N}_{2}$ ). There is now growing evidence that denitrification (bacterial or fungal) is the dominating process responsible for $\mathrm{N}_{2} \mathrm{O}$ losses from agricultural soils $[8,10,17]$. Therefore, in many agricultural field studies, $\mathrm{N}_{2} \mathrm{O}$ emission events are found in periods when high mineral nitrogen concentrations in soils coincide with high soil moisture (increasing the rate of denitrification) [7, 18].
The relevance of soil moisture can also be seen in field studies with similar climatic, soil, and substrate conditions, where $\mathrm{N}_{2} \mathrm{O}$ emissions nevertheless show significant inter-annual variability caused by the differences in soil water content [19]. These differences can usually be deduced from the weather records as they are related to the differences in the input of water through rainfall [18]. But the soil-water balance is also strongly influenced by the offtake of water through evapotranspiration. Crop plants play an important role, as they may transpire 500 to $600 \mathrm{~mm}$ of water per growth cycle which is 30 to $90 \%$ of the precipitation input in that period. In this respect, crops differ substantially, not only in the total amount of water that is transpired but also in the growth and transpiration pattern in the course of the year $[19,20]$.

Biofuels are often called " $\mathrm{CO}_{2}$ neutral" in the sense that $\mathrm{CO}_{2}$ which is emitted in the course of their combustion has previously been fixed from the atmosphere via photosynthesis during plant growth. Many industrialized countries have established ambitious policy targets and often offer financial incentives to stimulate the production or use of bioenergy. The main reasons for the promotion of biofuel production are that it is made from renewable resources (organic manures, plant materials, food waste), that it is expected to have no or even positive effect on the atmospheric greenhouse gas balance, and that it may reduce the dependency on fossil fuel [21]. However, biomass used for bioenergy generation is not per se environmentally benign, since its production is inevitably associated with negative side effects such as GHG emissions or $\mathrm{N}$ leaching. Soil $\mathrm{N}_{2} \mathrm{O}$ emissions are likely to be the dominating greenhouse gas emissions associated with bioenergy crop production [22]. It has been reported that the production and use of biofuels compared with the use of conventional fossil fuels may lead to a reduction or even increase in the total greenhouse gas emissions (72 to $107 \%$ ), depending on the type of bioenergy crop used and combustion technology chosen [23]. Here, the authors showed that $\mathrm{N}_{2} \mathrm{O}$ would typically make up 10 to $80 \%$ of the total greenhouse gas emissions in the biofuel production chain.

Intercropping, defined as any system of multiple cropping within the same space can be used as an alternate bioenergy cropping system [24]. The intercropping of cereals with legumes is particularly common, and introducing $\mathrm{N}_{2}$-fixing legumes into cereal-based crop rotations may reduce synthetic mineral $\mathrm{N}$-fertilizer use and thought to mitigate $\mathrm{N}_{2} \mathrm{O}$ fluxes. A reduction of $\mathrm{N}_{2} \mathrm{O}$ in tree-based intercropping systems has been reported [25]. In contrast, in a review study, Rochette and Janzen [26] concluded that legumes can produce substantial $\mathrm{N}_{2} \mathrm{O}$ emissions. The cultivation of $\mathrm{N}_{2}$-fixing legume species (e.g., faba bean (Vicia faba L.) as arable crop or Robinia 
(Robinia pseudoacacia) as woody plant) could stimulate $\mathrm{N}_{2} \mathrm{O}$ emissions simply by increasing $\mathrm{N}$ input to soils, thus providing additional substrate for nitrification and denitrification [27]. Authors reported that faba bean could release $13 \%$ of their fixed $\mathrm{N}$ as rhizodeposition [28]. Furthermore, denitrification by $\mathrm{N}$-fixing bacteria can be another source of $\mathrm{N}_{2} \mathrm{O}$ in legume domains [29].

As discussed above, $\mathrm{N}_{2} \mathrm{O}$ emissions vary greatly in space and time; thus, the direct comparison of soil $\mathrm{N}_{2} \mathrm{O}$ fluxes from various agro-ecosystems is certainly necessary and only very few studies are available on this subject. Therefore, our study aimed to evaluate two different agroecosystems (cropland and agro-forestry) cultivated in central Germany for their environmental impact. In a 1-year field experiment, we compared $\mathrm{N}_{2} \mathrm{O}$ fluxes from cropland (non-fertilized wheat, $\mathrm{N}$-fertilized wheat, non-fertilized faba bean, and wheat mixed intercropping with faba bean) and agro-forestry (non-fertilized poplar, N-fertilized poplar, non-fertilized Robinia, and poplar mixed intercropping with Robinia) as a randomized split-block design. Therefore, the objectives of the present study were (i) to obtain year-round $\mathrm{N}_{2} \mathrm{O}$ emission data in various agro-ecosystems (cropland and agro-forestry) in central Germany and (ii) to provide more knowledge on how a legume-based crop production system may affect $\mathrm{N}_{2} \mathrm{O}$ budget.

\section{Methods}

\section{Field experiment}

A field experiment was conducted at the research farm Reinshof $\left(51.49^{\circ} \mathrm{N}, 9.93^{\circ} \mathrm{E}, 150 \mathrm{~m}\right.$ asl $)$ of the GeorgAugust-University Göttingen, Germany. The continental climate leads to an average precipitation of $651 \mathrm{~mm}$ and a mean temperature of $9.2^{\circ} \mathrm{C}$. The rainfall and temperature at field site during the investigation period can be found in Fig. 1. Here, annual mean temperature and cumulative rainfall were $10.1{ }^{\circ} \mathrm{C}$ and $677 \mathrm{~mm}$ in 2014, respectively. The soil was classified as Haplic Luvisol according to the FAO classification system. At $0-30 \mathrm{~cm}$ soil section, the soil contained $15 \%$ clay, $73 \%$ silt, and $12 \%$ sand with a $\mathrm{pH}$ of 6.7 , and $0.1 \%$ total $\mathrm{N}$ and $1.0 \%$ total organic carbon content [30].

The 1-year field experiment (part of a large field trial) was set up in April 2014 with the aim of comparing $\mathrm{N}_{2} \mathrm{O}$ fluxes from the cropland (non-fertilized wheat (WT), N-fertilized wheat (NWT), non-fertilized faba bean (FB), wheat mixed intercropping with faba bean (WFB)), agro-forestry (non-fertilized poplar (PL), Nfertilized poplar (NPL), non-fertilized Robinia (RB), and poplar mixed intercropping with Robinia (PRB)) as a randomized split-block design. In the first year of the study, spring wheat (Triticum aestivum L.) cultivar Tybald and faba bean ( $V$. faba L.) cultivar Fuego were sown at the same time at the optimum planting date for

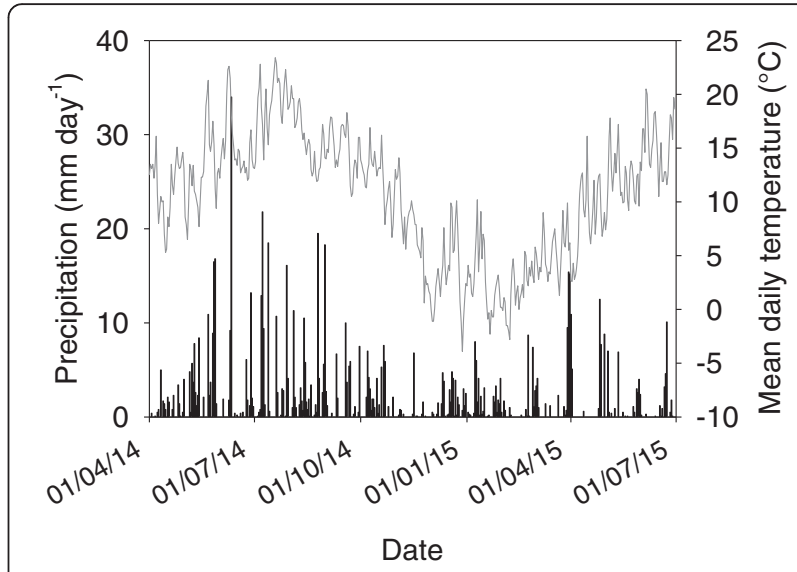

Fig. 1 Mean daily air temperature $\left[{ }^{\circ} \mathrm{C}\right]$ at canopy level (gray lines) and daily precipitation [mm day ${ }^{-1}$ ] (black bars) at experimental site Reinshof, Göttingen, in central Germany during the investigation period (April 2014-July 2015)

spring wheat (see Table 1 for details). Agro-forestry treatments consisted of poplar (Populus "Hybride 275") (PL); poplar mixed with Robinia ( $R$. pseudoacacia "HKG 81901") (PLR); Robinia (RB); and N-fertilized poplar (PLN). In the agro-forestry treatments, all trees were planted with 1 tree $\mathrm{m}^{-2}$ on 30 April 2014. Plot size was $5 \times 5 \mathrm{~m}$ for forest and $3 \times 9 \mathrm{~m}$ for arable treatments with three replications for each treatment. After the harvest of crop land in 2014, winter wheat (T. aestivum "genus"), wheat intercropped with winter bean ( $V$. faba "S_004"), mono-winter bean, and $\mathrm{N}$-fertilized wheat were seeded on 28 October 2014. Seeding density in the monocropped winter wheat plots was 320 plants $\mathrm{m}^{-2}$, intercropped plots were alternately seeded with wheat density of 160 plants $\mathrm{m}^{-2}$ and a bean density of 20 plants $\mathrm{m}^{-2}$, and mono-bean plots had a density of 40 plants $\mathrm{m}^{-2}$. Granular $\mathrm{N}$ fertilizer in the form of calcium-ammoniumnitrate was applied at a rate of $80 \mathrm{~kg} \mathrm{~N} \mathrm{ha}^{-1}$ as a single dressing to the soil surface on 15 May 2014 and 25 March 2015 in the respective treatments.

\section{Soil mineral $\mathbf{N}$}

For the analysis of soil mineral $\mathrm{N}$, soil from $0-15 \mathrm{~cm}$ depth was sampled extracted with a $0.0125 \mathrm{M} \mathrm{CaCl}_{2}$ solution $(1: 5 \mathrm{w} / \mathrm{v})$ and shaked for $1 \mathrm{~h}$. The extracts were then filtered with Whatman 602 filter paper and stored at $-20{ }^{\circ} \mathrm{C}$ until analysis. The extracts were analyzed colorimetrically for the concentrations of $\mathrm{NO}_{3}{ }^{-}$and $\mathrm{NH}_{4}^{+}$using the San++ continuous flow analyzer (Skalar Analytical B.V., Breda, The Netherlands).

\section{Trace gas flux measurement}

After the $\mathrm{N}$ application, gas samples were taken daily for a period of 1 week, followed by intervals of 2-3 days 
Table 1 Sowing dates and fertilizer application rate of each treatment

\begin{tabular}{|c|c|c|c|c|}
\hline Abbreviation & Crop & Fertilizer (kg CAN-N ha ${ }^{-1}$ ) & Stand & Date of sowing spring and winter crops \\
\hline WT & Spring wheat/winter wheat & None & Mono & 25 March 2014/28 October 2014 \\
\hline NWT & Spring wheat $+\mathrm{N} /$ winter wheat $+\mathrm{N}$ & 80 & Mono & 25 March 2014/28 October 2014 \\
\hline WFB & Mixed intercropping (wheat and faba bean) ${ }^{a}$ & None & Mixed intercrop & 25 March 2014/28 October 2014 \\
\hline FB & Field beans ${ }^{a}$ & None & Mono & 25 March 2014/28 October 2014 \\
\hline$P L$ & Poplar & None & Mono & 30 April 2014 \\
\hline NPL & Poplar & 80 & Mono & 30 April 2014 \\
\hline \multirow[t]{2}{*}{ PRB } & Mixed planting & None & Mixed planting & 30 April 2014 \\
\hline & Poplar/Robinia & & & \\
\hline $\mathrm{RB}$ & Robinia & None & Mono & 30 April 2014 \\
\hline
\end{tabular}

${ }^{\mathrm{a}}$ Information was given for both spring and winter crops

until the end of the vegetation period and once per week during the winter period using the closed chamber method described by Hutchinson and Mosier [31]. On each of 24 plots, basal rings made of polyvinyl chloride (PVC) (height $10 \mathrm{~cm}$, diameter $60 \mathrm{~cm}$ ) were pressed $5 \mathrm{~cm}$ into the soil. For the measurements, PVC chambers with an inner diameter of $60 \mathrm{~cm}$ and a height of $30 \mathrm{~cm}$ were put onto the basal rings, and tightened by a butyl rubber band all around the junction. The chambers were closed for $40 \mathrm{~min}$ within the period of $10.00-$ $14.00 \mathrm{~h}$ at each sampling day. Gas samples were taken from the chamber atmosphere at $0-20-40 \mathrm{~min}$ after closing the chamber using pre-evacuated 12-ml glass vials (Labco, Crewe, UK). The top of the PVC chambers were covered with white polystyrene to reflect solar radiation and have temperature stability within the chamber.

Concentrations of $\mathrm{N}_{2} \mathrm{O}$ were analyzed by a Bruker gas chromatography system (456-GC, Bruker, Billerica, USA) by deploying an electron capture detector (ECD) for $\mathrm{N}_{2} \mathrm{O}$. Operating conditions for the GC were as follows: injector temperature $95{ }^{\circ} \mathrm{C}$, column temperature $85{ }^{\circ} \mathrm{C}$, and detector temperature $320^{\circ} \mathrm{C}$. Samples were introduced using a Gilson auto-sampler (GX-281) (Gilson Inc., Middleton, WI, USA). Data processing was performed using the CompassCDS (vers. 3.0) software.

\section{Statistics}

Daily $\mathrm{N}_{2} \mathrm{O}$ flux rates for dates between sampling dates were calculated using linear interpolation, and annual cumulative $\mathrm{N}_{2} \mathrm{O}$ emissions were calculated as the sum of all daily flux rates for the vegetation period of each crop and the entire investigation periods during March 2014-August 2015. We used general linear model and Tukey's test for pairwise comparison of cumulative $\mathrm{N}_{2} \mathrm{O}$ flux between the treatments within each year. Statistical analyses were done using SPSS version 13.0.

\section{Results and discussion}

\section{Rainfall and crop production}

Rainfall at the site Reinshof was slightly over average during the period from 1 April to 1 July in 2014 (201 $\mathrm{mm}$ ) and considerably below average during the period from 1 April to 1 July in 2015 (100 mm). Therefore, the 2014 spring period was much wetter than spring 2015. Overall, 2014-2015 winter period was quite mild with no significant freeze-thaw event.

\section{Soil mineral $\mathbf{N}$}

The time course of the soil mineral-N concentrations are shown in Fig. 2. In soils planted with arable crops, soil $\mathrm{NH}_{4}^{+}$concentrations during the investigation period remained rather low (below $10 \mathrm{~kg} \mathrm{~N} \mathrm{ha}^{-1}$ at $30 \mathrm{~cm}$ layer) in non-fertilized treatments. The application of mineral$\mathrm{N}$ fertilizer in NWT treatment caused a slight increase in topsoil $\mathrm{NH}_{4}{ }^{+}$concentrations for a short time period which decreased rapidly to the background concentrations within a week. The low concentration of soil $\mathrm{NH}_{4}{ }^{+}$ even in $\mathrm{N}$-fertilized treatments (in the form of calciumammonium-nitrate) can be attributed to a rapid nitrification as soil texture and $\mathrm{pH}$ (6.7) serve ideal conditions for nitrification. In all treatments, there was a significant increase in topsoil $\mathrm{NH}_{4}{ }^{+}$concentrations in spring 2015 regardless from the $\mathrm{N}$ application. Early spring period in 2015 was reasonably dry compared to the same period in 2014. Therefore, the latter can be attributed to the processes related to the soil wetting after a long dry period (such as in spring 2015) which can accelerate $\mathrm{N}$ release from the mineralization of soil organic matter immediately after rewetting [32].

Overall treatments, soil $\mathrm{NO}_{3}{ }^{-}$concentrations in $0-15 \mathrm{~cm}$ soil segment varied between 10 and $85 \mathrm{~kg} \mathrm{NO}_{3}{ }^{-}-\mathrm{N} \mathrm{ha}^{-1}$. Here, $\mathrm{NO}_{3}{ }^{-}$was generally the dominant soil $\mathrm{N}$ form and highly variable when sampled soon after additions of fertilizer $\mathrm{N}$. In all soils, concentrations of $\mathrm{NO}_{3}{ }^{-}$in the $0-15$-cm layer decreased over time with the largest 

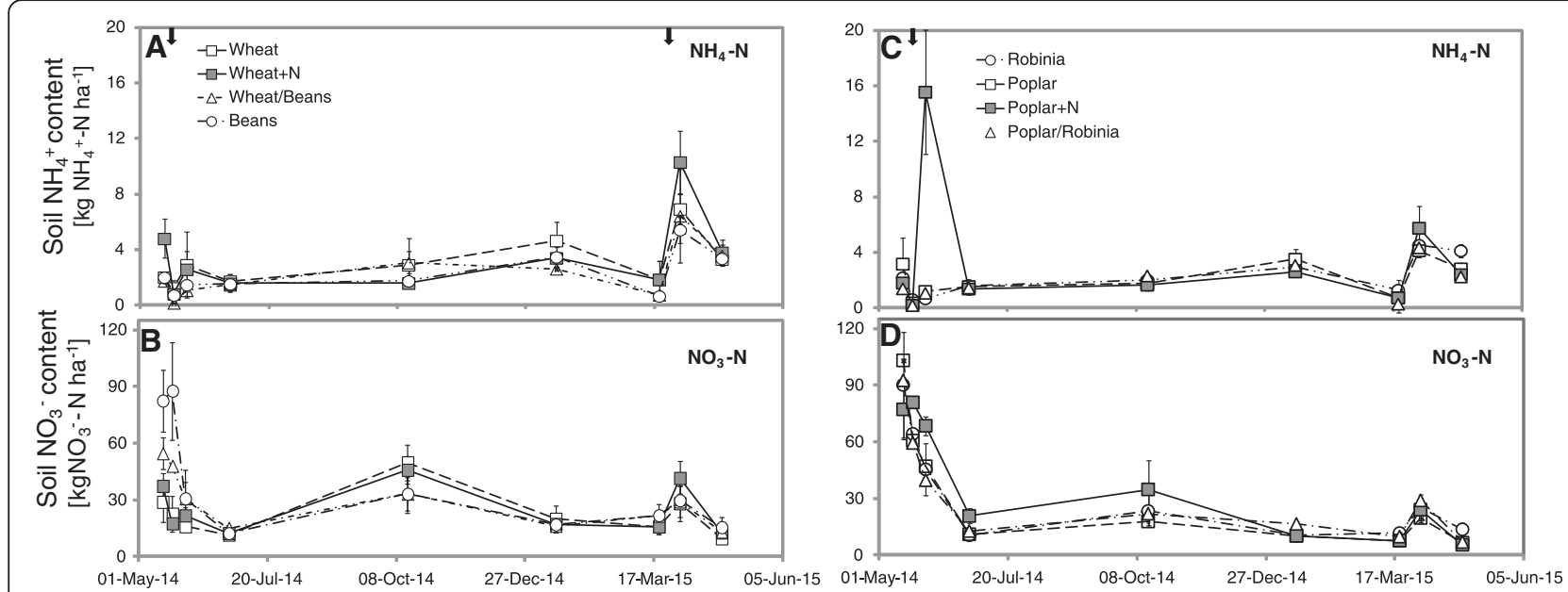

Fig. 2 Top soil (0-15 cm soil section) $\mathrm{NH}_{4}{ }^{+}(\mathbf{a}, \mathbf{c})$ and $\mathrm{NO}_{3}{ }^{-}$(b, d) content of the non-fertilized mono-crops (wheat (WT), faba bean (FB), poplar (PL), and Robinia (RB)), $\mathrm{N}$-fertilized mono-crops (80 $\mathrm{kg} \mathrm{N} \mathrm{ha}^{-1}$ in the form of calcium-ammonium-nitrate; wheat (NWT) and poplar (NPL)) and non-fertilized mixed crops (wheat with faba bean (WFB) and poplar with Robinia (PRB)). Vertical arrows above the charts indicate application dates of mineral fertilizers. Error bars show the standard error of the mean of each treatment $(n=3)$

decrease found in the arable crops specifically in WT and NWT treatments. During the vegetation period in 2014, soil $\mathrm{NO}_{3}{ }^{-}$content was generally higher in agroforestry soils than in arable soils. Plant nutrient and water uptake was expected to be higher in cropland compared to the young agro-forestry treatments in 2014 due to small size and low growth rate of young trees. Thus, more rapid depletion of soil mineral $\mathrm{N}$ in arable crops than agro-forestry treatments can mainly be attributed to the differences in plant $\mathrm{N}$ uptake.

In arable land stand, soil $\mathrm{NO}_{3}{ }^{-}$concentrations were clearly higher (significant in 2014, $p<0.01$ ) in FB than in other non-fertilized treatments during the vegetation period (Fig. 2a, b). For legume crops, inputs of biologically fixed $\mathrm{N}$ largely supplement to the uptake of soil mineral $\mathrm{N}$ to meet crop $\mathrm{N}$ demand. Thus, the legume species also take up mineral $\mathrm{N}$ from soils for growth before fixing additional $\mathrm{N}$. The preferential use of soil mineral $\mathrm{N}$ helps explain why there is also significant depletion of soil $\mathrm{NO}_{3}{ }^{-}$in $\mathrm{FB}$ treatment [33]. In a review study, authors reported that average $41 \%$ (for chickpea), $65 \%$ (for faba bean), and $66 \%$ (for field peas) of $\mathrm{N}$ that were present in legumes were derived from soil $\mathrm{N}$ [33]. However, slightly higher soil $\mathrm{NO}_{3}{ }^{-}$concentration in FB treatments than non-legume soils suggests that there were still reasonably more $\mathrm{NO}_{3}{ }^{-}$available for potential denitrification losses during the legume-growing season.

\section{Seasonal $\mathrm{N}_{2} \mathrm{O}$ emissions}

In both years, flux data indicate that $\mathrm{N}_{2} \mathrm{O}$ emissions were dominated by specific event periods (Fig. 3). Overall, maximum daily emissions of $\mathrm{N}_{2} \mathrm{O}$ in the early summer period in 2014 were $0.16 \pm 0.07$ and $0.04 \pm 0.01 \mathrm{~kg}$ $\mathrm{N}_{2} \mathrm{O}-\mathrm{N} \mathrm{ha}$ hay $^{-1}$ in agro-forestry and arable land treatments, respectively. In a 2-year field study, Lebender et al. [12] observed similar flux rates over a nearby site with similar soil conditions and agricultural practices (wheat and spring barley). Maximum $\mathrm{N}_{2} \mathrm{O}$ emissions measured in agro-forestry treatments $(0.16 \pm 0.07 \mathrm{~kg}$ $\mathrm{N}_{2} \mathrm{O}-\mathrm{N}$ ha $^{-1}$ day $^{-1}$ ) have been usually observed in young agro-forest ecosystems [7, 27]. Almost all significant $\mathrm{N}_{2} \mathrm{O}$ fluxes occurred as daily peak $\mathrm{N}_{2} \mathrm{O}$ emissions and were measured only during the early summer period in 2014 . The importance of these peak emissions in early summer period on the annual budget of $\mathrm{N}_{2} \mathrm{O}$ emissions highlights the necessity of continuous flux monitoring to accurately determine the $\mathrm{N}$ loss from agro-ecosystems specifically in spring and early summer seasons [7, 20].

In 2014, $\mathrm{N}_{2} \mathrm{O}$ emissions gradually decreased to the background levels (below $10 \mathrm{~g} \mathrm{~N}_{2} \mathrm{O}-\mathrm{N} \mathrm{ha}^{-1}$ day $^{-1}$ ) from the months of May to July and remained in background levels until March 2015 (Fig. 3). Interestingly, the latter was less than $0.01 \mathrm{~kg} \mathrm{~N}_{2} \mathrm{O}-\mathrm{N}$ ha $^{-1}$ day $^{-1}$ during the early summer period in 2015 for all treatments (including $\mathrm{N}$ fertilized treatments). As seen in Fig. 1, early summer period in 2014 was relatively wet (April-June, $201 \mathrm{~mm}$ rainfall) compared to the same period in 2015 (AprilJune, only $100 \mathrm{~mm}$ rainfall). Therefore, we may attribute higher daily $\mathrm{N}_{2} \mathrm{O}$ fluxes in 2014 than in 2015 (in early summer period) to the differences in mineral $\mathrm{N}$ and moisture content of the soil. Mineral N content of all soils in June 2014 was almost similar as compared to the same period in 2015, whereas $\mathrm{N}_{2} \mathrm{O}$ fluxes were still about 10fold higher in June 2014 than in June 2015. In this context, we may conclude that soil moisture seems to be the major 


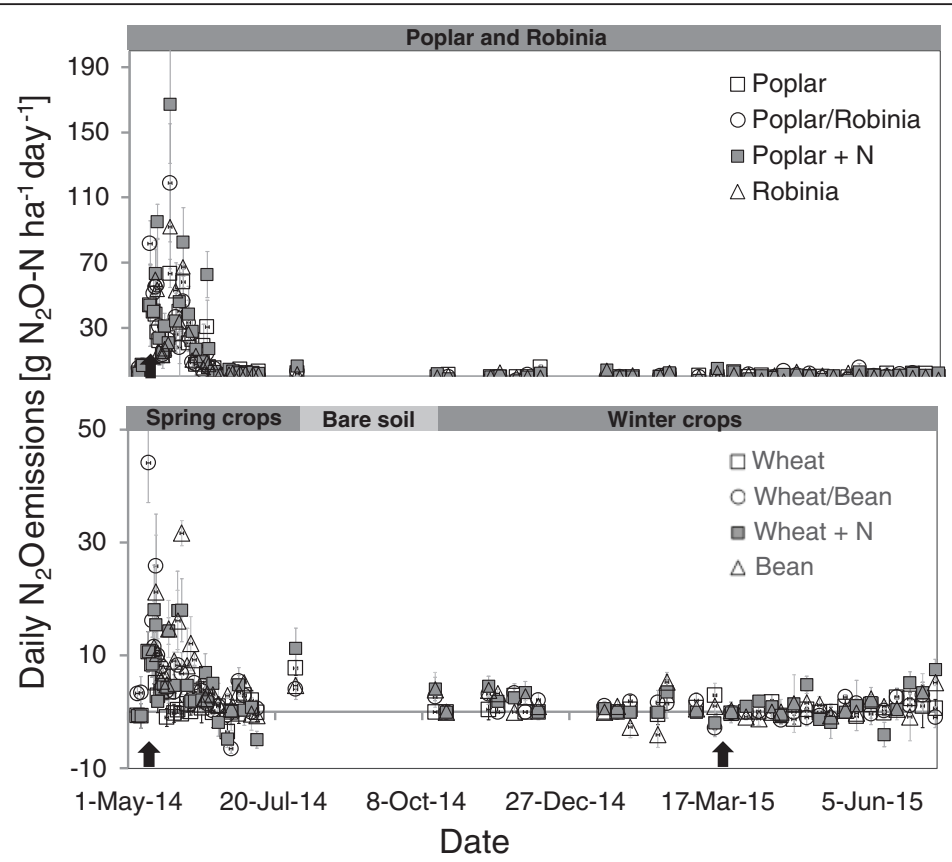

Fig. 3 Daily $\mathrm{N}_{2} \mathrm{O}$ fluxes of the non-fertilized mono-crops (wheat (WT), faba bean (FB), poplar (PL), and Robinia (RB)), N-fertilized mono-crops (80 kg N ha ${ }^{-1}$ in the form of calcium-ammonium-nitrate; wheat (NWT) and poplar (NPL)), and non-fertilized mixed crops (wheat with faba bean (WFB) and poplar with Robinia (PRB)). Vertical arrows under the charts indicate application dates of mineral fertilizers. Horizontal bars above the charts indicate growing periods of crops. Error bars show the standard error of the mean of each treatment $(n=3)$

driving factor of higher $\mathrm{N}_{2} \mathrm{O}$ emissions in the 2014 summer period than in 2015 .

All the abovementioned factors (e.g., high moisture, high soil temperature in early summer, and moderate or high $\mathrm{NO}_{3}{ }^{-}$content of the soil) are known to trigger specifically the denitrification rate in soils. Thus, we may speculate that denitrification (fungal or bacterial) was the potential key source of measured large $\mathrm{N}_{2} \mathrm{O}$ fluxes in the 2014 early summer period. Our earlier report supports this hypothesis in which sandy loam soil was incubated under laboratory conditions, and similar to the field experiment, large $\mathrm{N}_{2} \mathrm{O}$ peak events were observed immediately after rewetting of the soil. Here, a stable isotope-labeling study clearly showed that denitrification was the major source (over $90 \%$ of emitted $\mathrm{N}_{2} \mathrm{O}$ ) of large $\mathrm{N}_{2} \mathrm{O}$ peaks that occurred in wet seasons $[8,19]$. Furthermore, there is now a growing evidence that fungal denitrification may be the key process producing $\mathrm{N}_{2} \mathrm{O}$ in such situations rather than bacterial denitrification [17]. Surely, more research is needed to reveal (i) the dominant processes and (ii) key microbial or fungal strains producing $\mathrm{N}_{2} \mathrm{O}$ under these specific conditions (especially during early summer period).

\section{Effect of plant species on $\mathrm{N}_{2} \mathrm{O}$ emissions}

Mean cumulative $\mathrm{N}_{2} \mathrm{O}$ fluxes during the vegetation period in 2014 were $152 \pm 58,217 \pm 29$, and $441 \pm 10 \mathrm{~g}$
$\mathrm{N}_{2} \mathrm{O}-\mathrm{N} \mathrm{ha}{ }^{-1}$ in WT, WFB, and FB treatments, respectively. Among the non-fertilized arable crops (wheat, wheat mixed intercropped with bean, and bean), $\mathrm{N}_{2} \mathrm{O}$ emission over the 2014 growing seasons is highest in soils when faba bean (FB) was grown (Fig. 4). Introducing $\mathrm{N}$-fixing legumes into cereal-based crop rotations may reduce synthetic mineral- $\mathrm{N}$ fertilizer use and thought to mitigate $\mathrm{N}_{2} \mathrm{O}$ fluxes. However, the present study clearly showed that when faba bean was grown as a mono-crop, $\mathrm{N}_{2} \mathrm{O}$ fluxes were about threefold higher compared to WT treatment. In contrast to the present study, authors reported that growing season $\mathrm{N}_{2} \mathrm{O}$ emissions from $\mathrm{N}_{2}$-fixing legumes are significantly lower than from non-legumes and are often comparable to unfertilized background emissions [26, 34]. In line with the present study, Rochette and Janzen [26] (in a review study) concluded that legumes can produce substantial $\mathrm{N}_{2} \mathrm{O}$ emissions. They speculated that the main source of $\mathrm{N}_{2} \mathrm{O}$ emissions from soils planted with $\mathrm{N}_{2}$-fixing legumes during the vegetation period may be attributable to the $\mathrm{N}$ release from root exudates and/or from the decomposition of dead root residues. An alternative process that may contribute to the latter would be the $\mathrm{N}_{2} \mathrm{O}$ emission during the $\mathrm{N}_{2}$-fixation process in the nodules where $\mathrm{N}_{2}$ is fixed. Authors reported that several Rhizobium species in the free-living forms or in legume roots can denitrify $\mathrm{NO}_{3}{ }^{-}$and release $\mathrm{N}_{2} \mathrm{O}$ from active 


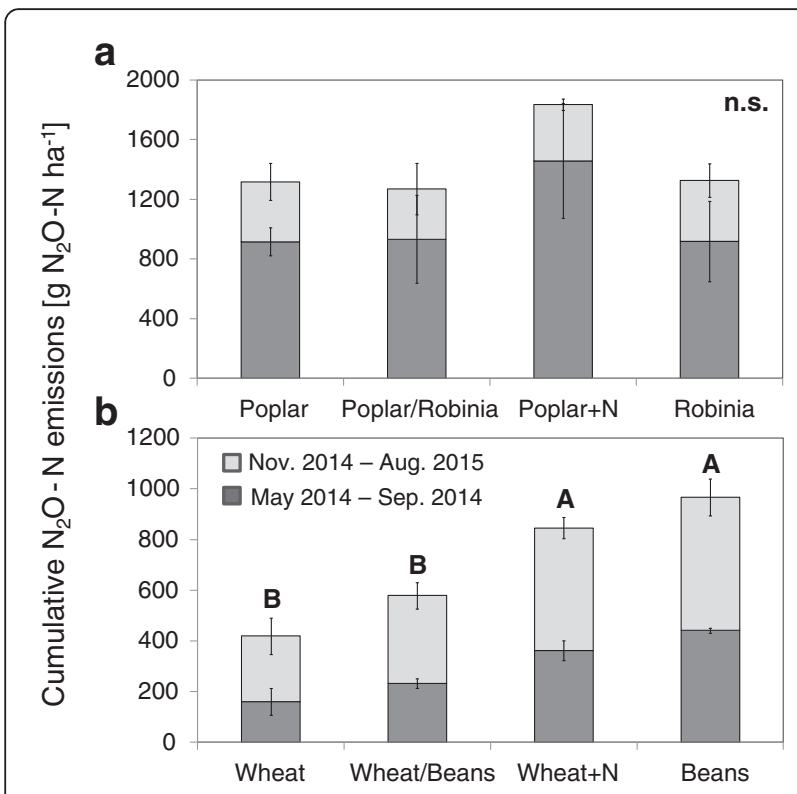

Fig. 4 Cumulative mean $\mathrm{N}_{2} \mathrm{O}$ emission rates of the non-fertilized mono-crops (wheat (WT), faba bean (FB), poplar (PL), and Robinia (RB)), $\mathrm{N}$-fertilized mono-crops (80 $\mathrm{kg} \mathrm{N} \mathrm{ha}^{-1}$ in the form of calcium-ammonium-nitrate; wheat (NWT) and poplar (NPL)) and non-fertilized mixed crops (wheat with faba bean (WFB) and poplar with Robinia (PRB)). Upper graphs (a) show the agro-forestry treatments, and lower graphs (b) show the crop domains during the period from May-September 2014 (vegetation period of spring crops) and November 2014 to August 2015. Error bars show the standard error of the mean of each treatment $(n=3)$. Means within each crop followed by the same letter $(A, B)$ are not significantly different $(p>0.05)$. n.s. not significant

nodules most likely to prevent excess $\mathrm{NO}_{3}{ }^{-}$that inhibits the activity of $\mathrm{N}_{2}$-fixing enzymes [35].

In agro-forestry treatments, both daily and cumulative $\mathrm{N}_{2} \mathrm{O}$ emissions did not differ among each other in the 2014 growing period. Here, mean seasonal $\mathrm{N}_{2} \mathrm{O}$ emissions (during the growing season of arable crops) were $1121 \pm 161,1102 \pm 159$, and $1052 \pm 266 \mathrm{~g} \mathrm{~N}_{2} \mathrm{O}-\mathrm{N} \mathrm{ha}{ }^{-1}$ in PL, PRB, and RB treatments (no significant difference), respectively. The cumulative mean $\mathrm{N}_{2} \mathrm{O}$ fluxes during the 2014 growth period were considerably higher in agro-forestry than in arable crop treatments. During the first year, young plantations in agro-forestry domains generally have limited $\mathrm{N}$ and water uptake, while wheat and faba bean as arable crops are at their most productive growth stage specifically during May and June (growth rates are almost at their maximum during this period). Here, soil conditions seem to be more favorable specifically for denitrification in agro-forestry treatments than in soils planted with arable crops that may explain large $\mathrm{N}_{2} \mathrm{O}$ emissions [27]. The cumulative mean $\mathrm{N}_{2} \mathrm{O}$ emissions in agro-forestry treatments were about fivefold higher than in both WT and WFB treatments, and the latter was still more than twofold higher when compared to FB plots. In line with the present data set, authors reported large $\mathrm{N}_{2} \mathrm{O}$ fluxes after conversion of pastures lands [7] or grasslands [36]. Here, authors attributed large $\mathrm{N}_{2} \mathrm{O}$ fluxes to the soil disturbance associated with tillage and cultivation that accelerate soil organic matter decomposition and microbial activity (nitrification and denitrification) leading to $\mathrm{N}_{2} \mathrm{O}$ emissions. In the present experiment, soil tillage has been done almost at the same time for all treatments. Thus, we may speculate that the difference in $\mathrm{N}_{2} \mathrm{O}$ emissions when comparing arable land to agro-forestry was mainly due to differences in water and nutrient uptake of plant species. Water and nutrient demand of young plantations during the first year are generally low which in return may cause more favorable conditions specifically for denitrification and $\mathrm{N}_{2} \mathrm{O}$ losses from denitrification. Overall, we can therefore summarize that direct plant effect seems to be one of the key variables that regulates $\mathrm{N}_{2} \mathrm{O}$ losses from soils. Zona et al. (2013) concluded that vegetation uptake of $\mathrm{NO}_{3}{ }^{-}$together with water ultimately may reduce the anaerobic volume of soils and may lower both denitrification rate and product stoichiometry of denitrification (lower $\mathrm{N}_{2} \mathrm{O} / \mathrm{N}_{2} \mathrm{O}+\mathrm{N}_{2}$ ratio; meaning reduced $\mathrm{N}_{2} \mathrm{O}$ and enhanced $\mathrm{N}_{2}$ production) in agricultural soils $[8,17]$.

\section{Effect of mineral $\mathrm{N}$ supply on $\mathrm{N}_{2} \mathrm{O}$ emissions}

Although it was not the main goal of the present experiment to study the effect of mineral- $\mathrm{N}$ addition on $\mathrm{N}_{2} \mathrm{O}$ fluxes, we added fertilizer $\mathrm{N}$ to mono-crop wheat (80 $\mathrm{kg} \mathrm{N} \mathrm{ha}^{-1}$; calcium-ammonium-nitrate) in parallel plots to be able to compare $\mathrm{N}_{2} \mathrm{O}$ fluxes from soils planted with $\mathrm{N}_{2}$-fixing plants (faba bean mono-culture or faba bean intercropped with wheat) with fertilized and non-fertilized wheat soils. $\mathrm{N}$ fertilization during the first year of new agro-forestry plantations is also not a common practice. However, $\mathrm{N}$ doses similar to the arable treatments were applied at the same date in order to be able to gain better scientific knowledge about the dominant factors regulating $\mathrm{N}_{2} \mathrm{O}$ fluxes in agro-forest ecosystems. Expectedly, in all $\mathrm{N}$-fertilizer treatments, $\mathrm{N}_{2} \mathrm{O}$ fluxes increased immediately after fertilizer application, however, only in 2014 (wet early summer) but no response observed in 2015 (dry early summer). The latter clearly suggests that environmental factors specifically soil moisture was the most dominant factor in 2014 that leads to relatively high $\mathrm{N}_{2} \mathrm{O}$ fluxes and without sufficient moisture or rainfall, fertilizer application alone does not affect $\mathrm{N}_{2} \mathrm{O}$ fluxes significantly, e.g., in 2015. In line with the present study, authors also reported that the application of organic or inorganic fertilizers affects $\mathrm{N}_{2} \mathrm{O}$ fluxes only in wet seasons but not in dry years $[10,17,19]$. 
Overall, the application of nitrogenous fertilizer affected $\mathrm{N}_{2} \mathrm{O}$ fluxes predominantly in cropland soils and had limited impact in agro-forestry soils. Here, cumulative $\mathrm{N}_{2} \mathrm{O}$ fluxes (from May to September 2014) were 46 and $121 \%$ higher in fertilized than in non-fertilized agro-forestry (non-fertilized poplar vs. fertilized poplar) or in cropland treatments (non-fertilized wheat vs. fertilized wheat), respectively. The latter clearly suggests that $\mathrm{N}_{2} \mathrm{O}$ fluxes were more dependent on soil mineral- $\mathrm{N}$ content in arable crops than in agro-forestry most likely due to greater competition between plants and $\mathrm{N}_{2} \mathrm{O}$ producing soil microorganisms in cropland than in agroforestry soils. Fertilizer-derived cumulative $\mathrm{N}_{2} \mathrm{O}$ emissions (emission factor) during the period from April to December 2014 were 0.21 and $0.45 \%$ of applied $\mathrm{N}$ in wheat and poplar soils, respectively. Measured emission factors were significantly lower than what IPCC predicts ( $1 \%$; [4]). However, the latter was similar to what we reported in our previous study for central and northern Germany $([12,19])$. For operational reasons in the present IPCC protocol, the $\mathrm{N}_{2} \mathrm{O}$ emission factor was set to $1 \%$ for all fertilizer $\mathrm{N}$ regardless of crop or soil type. Large variations in $\mathrm{N}_{2} \mathrm{O}$ emissions from different agricultural systems due to differences in management, climate, and soil type are very well known. Low $\mathrm{N}_{2} \mathrm{O}$ emission factors in the present experiment and in our previous reports suggest that in the future, different emission factors should be considered at least for different crops or regions that account for their different risks of $\mathrm{N}_{2} \mathrm{O}$ emissions.

Cumulative mean $\mathrm{N}_{2} \mathrm{O}$ emission during the growing season was still $31 \%$ higher $(p<0.05)$ in FB than in NWT treatment. In a review study, Rochette and Jansen [26] summarized that legumes can increase $\mathrm{N}_{2} \mathrm{O}$ emissions during growth compared to evenly fertilized arable crops most likely due to the $\mathrm{N}$ release from the root exudates and decomposition of crop residues. Our study clearly agrees with Rochette and Jansen [26] and many others (e.g., $[7,27])$ that growing legumes as mono-crop can increase $\mathrm{N}_{2} \mathrm{O}$ fluxes compared to $\mathrm{N}$-fertilized arable crops. On the other hand, seasonal $\mathrm{N}_{2} \mathrm{O}$ fluxes were $35 \%$ lower in WFB (wheat mixed intercropped with faba bean) than in NWT (wheat as mono-crop) treatment. The latter suggests that using legume crops as intercrop or mixed crop in wheat may significantly mitigate fertilizer-derived $\mathrm{N}_{2} \mathrm{O}$ fluxes. However, surely more research is needed to upscale current findings due to the complexity and variability of $\mathrm{N}_{2} \mathrm{O}$ fluxes in complex agricultural systems, e.g., mixed cropping systems.

\section{Conclusions}

The $\mathrm{N}_{2} \mathrm{O}$ emission from soils is variable in space and time, thus measuring and quantifying variance in $\mathrm{N}_{2} \mathrm{O}$ emissions is rather difficult, and there are only few field experiments available allowing long-term comparison of various plant species (crops, legumes, and agro-forests) simultaneously with fertilizer effects. We see three take home messages:

- Currently, biogas production from energy crops is mainly based on anaerobic fermentation of mono-crops; however, high-yielding mono-crops require high $\mathrm{N}$-fertilizer input that increases the risk of $\mathrm{N}_{2} \mathrm{O}$ losses. Present study clearly showed that mixed intercropping agricultural systems (legume and non-legume plant species) may significantly lower (about $35 \%$ ) $\mathrm{N}_{2} \mathrm{O}$ losses compared to the $\mathrm{N}$-fertilized mono-crops.

- Cumulative $\mathrm{N}_{2} \mathrm{O}$ emissions in agro-forestry soils were about 2-5-fold higher than in cropland soils. Soil conditions in agro-forestry treatments seem to be more favorable specifically for denitrification (due to limited water and nutrient uptake of young plantations during their initial growth stage) than soils planted with arable crops that may be responsible for large $\mathrm{N}_{2} \mathrm{O}$ emissions.

- Cumulative mean $\mathrm{N}_{2} \mathrm{O}$ emissions during the growth period of annual crops were $31 \%$ higher $(p<0.05)$ in soils planted with faba bean than in $\mathrm{N}$-fertilized wheat. We can conclude that legumes (when grown alone) can produce substantial $\mathrm{N}_{2} \mathrm{O}$ emissions most likely due to enhanced denitrification activity in their rhizosphere due to $\mathrm{N}$-rich root exudates/ dead organic matter.

Competing interests

The authors declare that they have no competing interests.

Authors' contributions

MS contributed to the acquisition of funding, supervised the field work, perform the statistics, and drafted the paper (50\%). CW as a MSc student run the experiment ( $70 \%$; gas sampling, soil sampling, and analysis), collected and analyzed the data, and drafted the paper (10\%). AL as a PhD student contributed to the field experiment (crop management, soil sampling, and data analysis), and drafted the paper (5\%). JI contributed to the acquisition of funding and design of the experiment and drafted the paper (5\%). HS contributed to the acquisition of funding, participated to the design of the experiment, and drafted the paper (5\%). CK drafted the paper and contributed to the planning of the experiment. SK as a PhD student contributed to the field experiment (crop management, soil sampling, and analysis), supervised the MSc student, and drafted the paper (25\%). All authors read and approved the final manuscript.

\section{Acknowledgements}

This study was funded by the Federal Ministry of Education and Research (FKZ 031A351A). IMPAC ${ }^{3}$ is a project of the Centre of Biodiversity and sustainable Land Use at the University of Gottingen.

\section{Author details}

'Institute of Applied Plant Nutrition, University of Gottingen, Carl-Sprengel-Weg 1, Gottingen 37075, Germany. ${ }^{2}$ Present Address: Department of Plant Nutrition and Soil Science, University of Harran, SanliUrfa TR-63000, Turkey. ${ }^{3}$ Department Crop Science, Grassland Science, University of Gottingen, Gottingen 37075, Germany. ${ }^{4}$ Department Biodiversity and Sustainable Land Use, University of Gottingen, Gottingen 37077, Germany. ${ }^{5}$ Department Crop Science, Plant Nutrition and Soil Science, University of Gottingen, Gottingen 37075, Germany. 
Received: 11 August 2015 Accepted: 8 December 2015

Published online: 16 January 2016

\section{References}

1. Ravishankara AR, Daniel JS, Portmann RW (2009) Nitrous oxide (N2O): the dominant ozone-depleting substance emitted in the 21st Century. Science 326:123-125. doi:10.1126/science.1176985

2. Smith KA, Mosier AR, Crutzen PJ, Winiwarter W (2012) The role of N2O derived from crop-based biofuels, and from agriculture in general, in Earth's climate. Philos Trans R Soc Lond B Biol Sci 367:1169-1174. doi:10.1098/rstb. 2011.0313

3. Fluckiger J, Monnin E, Stauffer B, Schwander J, Stocker TF. (2002) Highresolution Holocene $\mathrm{N} 2 \mathrm{O}$ ice core record and its relationship with $\mathrm{CH} 4$ and CO2. Glob Biogeochem Cycles 16:1010. doi:10.1029/2001GB001417

4. IPCC Fourth Assessment Report: Climate Change 2007 (AR4). https://www.ipcc ch/publications_and_data/ar4/syr/en/contents.html. Accessed 5 Aug 2015

5. Kroeze C, Mosier A, Bouwman L (1999) Closing the global N2O budget: a retrospective analysis 1500-1994. Glob Biogeochem Cycles 13:1-8. doi:10.1029/1998GB900020

6. Davidson E (1992) Sources of nitric-oxide and nitrous-oxide following wetting of dry soil. Soil Sci Soc Am J 56:95-102

7. Zona D, Janssens IA, Gioli B, Jungkunst HF, Serrano MC, Ceulemans R. (2013) $\mathrm{N} 2 \mathrm{O}$ fluxes of a bio-energy poplar plantation during a two years rotation period. GCB Bioenergy 5:536-547. doi:10.1111/gcbb.12019

8. Senbayram M, Chen R, Mühling KH, Dittert K (2009) Contribution of nitrification and denitrification to nitrous oxide emissions from soils after application of biogas waste and other fertilizers. Rapid Commun Mass Spectrom RCM 23:2489-2498. doi:10.1002/rcm.4067

9. Bergstermann A, Cardenas L, Bol R, Gilliam L, Goulding K, Meijide A, et al. (2011) Effect of antecedent soil moisture conditions on emissions and isotopologue distribution of N2O during denitrification. Soil Biol Biochem 43:240-250. doi:10.1016/j.soilbio.2010.10.003

10. Dobbie KE, Smith KA (2001) The effects of temperature, water-filled pore space and land use on N2O emissions from an imperfectly drained gleysol. Eur J Soil Sci 52:667-673. doi:10.1046/j.1365-2389.2001.00395x

11. Bouwman AF, Boumans LJM, Batjes NH (2002) Emissions of N2O and NO from fertilized fields: summary of available measurement data. Glob Biogeochem Cycles 16:1058. doi:10.1029/2001GB001811

12. Lebender U, Senbayram M, Lammel J, Kuhlmann H (2014) Impact of mineral $\mathrm{N}$ fertilizer application rates on $\mathrm{N} 2 \mathrm{O}$ emissions from arable soils under winter wheat. Nutr Cycl Agroecosystems 100:111-120. doi:10.1007/ s10705-014-9630-0

13. Weier K, Doran J, Power J, Walters D (1993) Denitrification and the dinitrogen nitrous-oxide ratio as affected by soil-water, available carbon, and nitrate. Soil Sci Soc Am J 57:66-72

14. Morkved PT, Dorsch P, Henriksen TM, Bakken LR (2006) N2O emissions and product ratios of nitrification and denitrification as affected by freezing and thawing. Soil Biol Biochem 38:3411-3420. doi:10.1016/j.soilbio.2006.05.015

15. Metay A, Chapuis-Lardy L, Findeling A, Oliver R, Alves Moreira JA, Feller C. (2011) Simulating N2O fluxes from a Brazilian cropped soil with contrasted tillage practices. Agric Ecosyst Environ 140:255-263. doi:10.1016/j.agee.2010. 12.012

16. Saggar S (2010) Estimation of nitrous oxide emission from ecosystems and its mitigation technologies preface. Agric Ecosyst Environ 136:189-191. doi:10.1016/j.agee.2010.01.007

17. Koester JR, Well R, Dittert K, Giesemann A, Lewicka-Szczebak D, Mühling KH, et al. (2013) Soil denitrification potential and its influence on N2O reduction and N2O isotopomer ratios. Rapid Commun Mass Spectrom 27:2363-2373. doi:10.1002/rcm.6699

18. Jungkunst HF, Fiedler S, Stahr K (2004) N2O emissions of a mature Norway spruce (Picea abies) stand in the Black Forest (southwest Germany) as differentiated by the soil pattern. J Geophys Res Atmos 109:D07302. doi:10.1029/2003JD004344

19. Senbayram M, Chen R, Wienforth B, Herrmann A, Kage H, Mühling KH, et al. (2014) Emission of $\mathrm{N} 2 \mathrm{O}$ from biogas crop production systems in Northern Germany. Bio Energy Res 7:1223-1236. doi:10.1007/s12155-014-9456-2

20. Drury CF, Reynolds WD, Tan CS, McLaughlin NB, Yang XM, Calder W, et al. (2014) Impacts of 49-51 years of fertilization and crop rotation on growing season nitrous oxide emissions, nitrogen uptake and corn yields. Can J Soil Sci 94:421-433. doi:10.4141/CJSS2013-101
21. Herrmann A (2013) Biogas production from maize: current state, challenges and prospects. 2. Agronomic and environmental aspects. Bio Energy Res 6:372-387. doi:10.1007/s12155-012-9227-x

22. Cherubini F, Jungmeier G (2010) LCA of a biorefinery concept producing bioethanol, bioenergy, and chemicals from switchgrass. Int J Life Cycle Assess 15:53-66. doi:10.1007/s11367-009-0124-2

23. Smeets EMW, Bouwmanw LF, Stehfest E, Van Vuuren DP, Posthuma A. (2009) Contribution of N2O to the greenhouse gas balance of firstgeneration biofuels. Glob Chang Biol 15:1-23. doi:10.1111/j.1365-2486.2008. 01704.x

24. Whitmore AP, Schroder JJ (2007) Intercropping reduces nitrate leaching from under field crops without loss of yield: a modelling study. Eur J Agron 27:81-88. doi:10.1016/j.eja.2007.02.004

25. Beaudette C, Bradley RL, Whalen JK, McVetty PBE, Vessey K, Smith DL. (2010) Tree-based intercropping does not compromise canola (Brassica napus L.) seed oil yield and reduces soil nitrous oxide emissions. Agric Ecosyst Environ 139:33-39. doi:10.1016/j.agee.2010.06.014

26. Rochette $\mathrm{P}$, Janzen HH (2005) Towards a revised coefficient for estimating N2O emissions from legumes. Nutr Cycl Agroecosystems 73:171-179. doi:10.1007/s10705-005-0357-9

27. Liu XP, Zhang WJ, Hu CS, Tang XG (2014) Soil greenhouse gas fluxes from different tree species on Taihang Mountain, North China. Biogeosciences 11:1649-1666. doi:10.5194/bg-11-1649-2014

28. Mayer J, Buegger F, Jensen ES, Schloter M, Heß J. (2003) Estimating N rhizodeposition of grain legumes using a N-15 in situ stem labelling method. Soil Biol Biochem 35:21-28. doi:10.1016/S0038-0717(02)00212-2

29. Breitenbeck G, Bremner J (1989) Ability of free-living cells of bradyrhizobiumjaponicum to denitrify in soils. Biol Fertil Soils 7:219-224. doi:10.1007/ BF00709652

30. Müller E, Rottmann N, Bergstermann A, Wildhagen, H, Joergensen RG. (2011) Soil CO2 evolution rates in the field-a comparison of three methods. Arch Agron Soil Sci 57:597-608. doi:10.1080/03650340.2010.485984

31. Hutchinson GL, Mosier AR (1981) Improved soil cover method for field measurement of nitrous oxide fluxes1. Soil Sci Soc Am J 45:311. doi:10.2136/ sssaj1981.03615995004500020017x

32. Xiang S-R, Doyle A, Holden PA, Schimel JP (2008) Drying and rewetting effects on $\mathrm{C}$ and $\mathrm{N}$ mineralization and microbial activity in surface and subsurface California grassland soils. Soil Biol Biochem 40:2281-2289. doi:10.1016/j.soilbio.2008.05.004

33. Unkovich M (2012) Nitrogen fixation in Australian dairy systems: review and prospect. Crop Pasture Sci 63:787-804. doi:10.1071/CP12180

34. Jeuffroy MH, Baranger E, Carrouee B, de Chezelles E, Gosme M, Hénault C, et al. (2013) Nitrous oxide emissions from crop rotations including wheat, oilseed rape and dry peas. Biogeosciences 10:1787-1797. doi:10.5194/ bg-10-1787-2013

35. Rosen A, Lindgren PE, Ljunggren H (1996) Denitrification by Rhizobium meliloti.1. Studies of free-living cells and nodulated plants. Swed J Agric Res 26:105-113

36. Gelfand I, Zenone T, Jasrotia P, Chen J, Hamilton SK, Robertson GP. (2011) Carbon debt of conservation reserve program (CRP) grasslands converted to bioenergy production. Proc Natl Acad Sci U S A 108:13864-13869. doi:10. 1073/pnas.1017277108

\section{Submit your manuscript to a SpringerOpen ${ }^{\circ}$ journal and benefit from:}

- Convenient online submission

- Rigorous peer review

- Immediate publication on acceptance

- Open access: articles freely available online

- High visibility within the field

- Retaining the copyright to your article

Submit your next manuscript at $>$ springeropen.com 